\author{
Anna Wróbel \\ University of Warsaw \\ e-mail: awrobel@uw.edu.pl
}

\title{
THE ROLE OF NON-GOVERNMENTAL
}

ORGANIZATIONS IN TRADE POLICY - CASE STUDY

OF CAMPAIGNS AGAINST TTIP AND CETA IN GERMANY

ROLA ORGANIZACJI POZARZĄDOWYCH

W POLITYCE HANDLOWEJ - STUDIUM PRZYPADKU

KAMPANII PRZECIW TTIP I CETA W NIEMCZECH

DOI: $10.15611 /$ pn.2018.523.33

JEL Classification: F00, F13, F19, F50

Summary: The aim of this article is to analyze the role of NGOs in organizing public opposition to trade liberalisation on the example of the campaign against TTIP and CETA in Germany. The study was divided into two parts. The first part analyses the increasing importance of NGOs in trade policy, using as an example the actions against the multilateral trading system of the WTO and the chosen preferential trade arrangements. The second part of the study focuses on non-state actors' activities in Germany opposing the CETA and TTIP negotiations.

Keyword: Germany, NGOs, free trade, liberalisation, civil society, EU, TTIP, CETA.

Streszczenie: Celem artykułu jest analiza roli organizacji pozarządowych w organizowaniu społecznego sprzeciwu wobec liberalizacji handlu na przykładzie kampanii przeciwko TTIP i CETA w Niemczech. Opracowanie podzielone zostało na dwie części. W pierwszej przeanalizowano wzrost znaczenia organizacji pozarządowych $\mathrm{w}$ polityce handlowej na przykładzie działań skierowanym przeciwko wielostronnemu systemu handlowemu WTO oraz wybranym preferencyjnym porozumieniom handlowym. Część druga opracowania koncentruje się na aktywności podmiotów niepaństwowych w Niemczech sprzeciwiających się rokowaniom CETA i TTIP.

Słowa kluczowe: Niemcy, NGOs, wolny handel, liberalizacja, społeczeństwo obywatelskie, UE, TTIP, CETA. 


\section{Introduction}

The issue of liberalization of transatlantic trade on the basis of free trade agreements between the European Union and Canada, and between the European Union and the United States has been the subject of intense public debate in Germany. Not only politicians and representatives of the world of science demonstrated significant activity in the discussion about benefits and threats associated with assuming the Comprehensive Economic and Trade Agreement (CETA) between the EU and Canada, and in the negotiations of the Transatlantic Trade and Investment Agreement (TTIP), but also numerous non-governmental organizations representing interests of employers, employees, consumers as well as church organizations involved in environmental protection and opposing globalization. Concerns about negative effects of CETA and TTIP have prompted many German citizens to participate in demonstrations against the conclusion of these agreements. The purpose of this article is to analyse the role of non-governmental organizations in the organization of social opposition against the liberalization of trade on the example of campaigns against TTIP and CETA in Germany ${ }^{1}$.

\section{The role of non-governmental organizations in trade policy}

In recent decades, not only the number, but also the significance of non-governmental organizations - both national and international - have increased in particular countries as well as on the international arena. The increase in significance of such entities results mostly from an increased impact on public opinion, in particular in matters associated with globalization or environmental protection. Effective impact on public opinion by such entities also allows decisions made by authorities of individual countries and organs of international organizations to be affected. The growing importance of non-state actors should be associated with the complexity of problems of the modern world. International society must meet many challenges such as overcoming poverty and hunger, limiting population growth, protecting the environment, combating climate change, ensuring world peace. The scale and complexity of the above-mentioned problems requires the involvement of numerous entities, including non-governmental organizations, in order to solve them or to mitigate their severity. The potential of such entities was observed when the United Nations system was created. Under the pressure of the United States an article providing for a requirement of consultations between the Social and Economic Council (ECOSOC) and non-governmental organizations was introduced (art. 71) [Willestts 2008].

1 This article is part of the „Global Economic Governance - Actors, Areas of Influence, Interactions" research project (OPUS, UMO-2016/23/B/HS5/00118) funded by the National Science Centre, Poland. 
In the field of trade policy, a significant increase in involvement of nongovernmental organizations has been observed especially since the $90 \mathrm{~s}$ of the $20^{\text {th }}$ century. NGOs have actively joined the public debate concerning the consequences of globalization and threats related to the process. This activity was manifested in protests against trade liberalization both in the global and regional dimension. A spectacular example of such actions was a protest on the streets of Seattle during the ministerial conference of the World Trade Organization (WTO) in 1999. Nearly thirty thousand opponents of globalization, including trade unionists, members of environmental protection organizations and religious groups participated in it. Demonstrators not only expressed reservations about specific WTO actions, but also referred to a number of other issues ranging from genetically modified cereals and child labour, to the US embargo on Cuba and the need to protect turtles. What united the protesters was the lack of confidence in the WTO, although many of them had only limited knowledge about this organization. However, it shows the efficiency of actions of the Direct Action Network which was able to gather such a number of people on the streets so that some commentators believed that these protests constituted the most serious civil disobedience in the United States since the $60 \mathrm{~s}$ of the $20^{\text {th }}$ century [Hoekman, Kostecki 2002].

Not only multilateral negotiations aroused concern and provoked a response from civil society, but also bilateral and sectoral negotiations. In the second half of the $80 \mathrm{~s}$ of the $20^{\text {th }}$ century - due to concerns regarding effects of trade liberalization in Canada, various groups opposed negotiations in terms of an agreement establishing a free trade zone with the United States (Canada-United States Free Trade Agreement, CUSFTA). Attention was drawn not only to the disproportions between the economy of the United States and Canada, and therefore the possibility of unequal distribution of benefits from free trade, but also to threats to cultural identity and political independence. An important issue discussed at that time also involved environmental protection and social policy. To coordinate actions of various non-governmental organizations, trade unions, industry groups, environmental protection, women's organizations, cultural and religious organizations, the Pro-Canada Network was created. Important participants of the public debate concerning CUSFTA in Canada were among others the Canadian Labour Congress, the National Action Committee on the Status of Women, the National Farmers Union and the Ecumenical Coalition for Economic Justice. Variety of entities participating in the debate on CUSFTA and the cooperation between them significantly contributed to increased knowledge of the Canadian society about various aspects and consequences of the trade agreement entering into force. Actions undertaken by non-governmental entities forced the ruling conservatives to carry out an intensive information campaign to accept the agreement and benefits related to it. The approach to CUSFTA also became an element of the political game between the main Canadian political parties during parliamentary elections in Canada [Strange 2014; Hueyer 2004]. 
Cooperation between various groups and Canadian organizations, commenced during the negotiations of CUSFTA, was continued in relation to the project of creating the North American Free Trade Agreement (NAFTA). In this case, coordination of actions of non-governmental organizations was significantly extended. Opposition against NAFTA brought together NGOs from three future members of the agreement. More experienced Canadian organizations not only initiated cooperation with their counterparts from the United States and Mexico, but also collected funds financing trilateral projects [Strange 2014]. Coordinated actions of many entities from different countries that took place during the organization of social opposition to NFTA and then in relation to the newly created World Trade Organization as well as the scale of these activities started to significantly influence the global governance of global trade. Among traditional actors who tried to influence the state's trade policy (exporters, importers, industry associations, trade unions, consumer organizations), transnational entities have emerged, the purpose of which was not only to affect countries and the direction of trade policy in bilateral relationships implemented by them, but also through lobbying countries to a large extent impact the functioning of the global trade governance system related to the WTO's activity [Murphy 2010].

The above-mentioned protests highlighted a strong relationship between trade on one hand, and issues of environmental protection, employees' rights and children's welfare on the other. Emphasizing the social costs of globalization, including trade liberalization, non-governmental organizations pointed out that this process cannot take place at the expense of the natural environment and weaker units. Among slogans that reflect this position of civil society well, inter alia the following should be listed: "Globalization with human face" or "Another world is possible". A reflection of the above-mentioned issues in modern trade agreements and at least a partial response to threats indicated by NGOs involves including environmental protection and employee's rights in trade agreements with an increasing frequency and highlighting the need to undertake actions for sustainable development.

\section{Opposition to TTIP and CETA in Germany}

Non-governmental organizations in Germany have actively participated in the discussion on the potential effects of transatlantic trade agreements. Activities of organizations opposing TTIP and CETA negotiations were particularly visible and broadly commented in the media. Among others, such organizations prepared and published information materials indicating threats resulting from transatlantic trade liberalization, organizing and encouraging people to participate in protests and sign petitions against TTIP.

The campaign against trade agreements negotiated by the European Commission intensified especially with the opening of subsequent rounds of TTIP and CETA negotiations, during the visit of US President Barack Obama to the industrial fair 
in Hannover and in the final period of CETA negotiations as well as during the process of ratifying the agreement with Canada. For instance, during European demonstrations against TTIP (and CETA) on 10 October 2015 in Germany from 100 thousand to 250 thousand people (depending on whether the police or the organizers provided numerical data) participated in the demonstrations. On the occasion of Barack Obama's visit to industrial fairs on Saturday, April 23, 2016 according to the police thirty thousand people went out on the streets of Hanover [Stasik 2016]. Mass protests against TTIP and CETA also took place on September 17, 2016 in seven German cities (Berlin, Hamburg, Munich, Leipzig, Cologne, Frankfurt am Main, Stuttgart). Protests were organized by a coalition of more than thirty nongovernmental organizations (among others WWF, Oxfam and Greenpeace), political parties (the Green, SPD, Die Linke), trade unions (including ver.de), think tanks, consumer organizations and even small church initiatives. Under the slogan "Stop TTIP and CETA - for fair world trade" protesters demanded that works on TTIP be ceased immediately and that the ratification process of CETA be abandoned [Rozwadowska 2016a]. Analysing the number of participants of demonstrations in Germany, it can be stated that Germany is an EU country where TTIP and CETA negotiations aroused the greatest public interest.

Apart from demonstrations, a tool which was supposed to contribute to consideration of the public opinion in the debate against trade liberalization based on TTIP was a petition of the European Citizens' Initiative "Stop TTIP"2. Organizations associated under the initiative wanted to encourage the EU to cease negotiations with the United States3. Among German non-governmental organizations, among others German ATTAC and Friends of the Earth Germany participated in "Stop TTIP" [Metzner 2014]. Signatures for the petition were collected for a year. According to the initiative data, by October 6 2015, when the event was finished, 3.2 million signatures were collected in $23 \mathrm{EU}$ countries [https://stop-ttip.org/about-stop-ttip].

Critics of the agreement recall a whole series of arguments showing CETA, TTIP as well as the plurilateral Trade in Services Agreement in a negative light. Arguments against TTIP, CETA and TISA published by a German branch of ATTAC are presented in table 1. Due to limitations of the article, only some of them - most often mentioned in the public debate - will be presented.

2 Citizens' initiatives constitute an instrument that enables EU citizens to directly contact the Commission to propose legislation in the area for which the EU is responsible, provided that they can collect one million signatures (including a minimum number of signatures in at least seven EU Member States).

3 The European Commission refused to register the European Citizens' Initiative "Stop TTIP". It was considered that the decision to withdraw the authorization to open negotiations is not covered by the term of "legal act". Despite the lack of registration, the organizers decided to continue the campaign to collect signatures. The Commission's decision was also appealed against to the Court of Justice [T754/14]. On $10^{\text {th }}$ of May 2017 the Court of Justice annulled the Commission's decision C(2014) 6501 final decision dated $10 \mathrm{t}^{\mathrm{h}}$ of September 2014 on the refusal to register the proposed European Citizens' Initiative named "Stop TTIP". 
Table 1. Thirty-eight arguments against TTIP, CETA and TiSA

\begin{tabular}{|c|c|}
\hline $\begin{array}{l}\text { 1. TTIP brings us closer to the new block } \\
\text { confrontation. } \\
\text { 2. The more we deregulate global markets, the } \\
\text { more we divide the world. } \\
\text { 3. TTIP - strengthening competition and blind } \\
\text { economic growth. } \\
\text { 4. TTIP leads to authoritarian statehood. } \\
\text { 5. Investment protection and the right to sue } \\
\text { constitute a strong weapon in the fight against } \\
\text { politics. } \\
\text { 6. Enterprises obtaining the right to sue } \\
\text { constitutes an attack on environmental protection } \\
\text { and consumers. } \\
\text { 7. ISDS is primarily the success of lawyers. } \\
\text { 8. ISDS reforms are an attempt to save an } \\
\text { instrument protecting corporate interests. } \\
\text { 9. TTIP - unilateral lobbying prevents a } \\
\text { balanced range of treaties. } \\
\text { 10. Corporate lobbying and lobbying of the } \\
\text { Commission are based on disinformation and } \\
\text { manipulation. } \\
\text { 11. TTIP and CETA are tools against } \\
\text { democratic decisions. } \\
\text { 12. Regulatory cooperation is a tool to } \\
\text { implement interests of corporations. } \\
\text { 13. An example of a threatening activity: } \\
\text { OIRA* - American Information and Regulatory } \\
\text { Office. } \\
\text { 14. TTIP is an instrument of power against the } \\
\text { countries of the South. } \\
\text { 15. Sustainable trade policy should include } \\
\text { developing countries. } \\
\text { 16. TTIP jeopardizes jobs and our level of } \\
\text { wages. } \\
\text { 17. TTIP threatens small and medium } \\
\text { enterprises. } \\
\text { 18. Threat to the balance of enterprises. }\end{array}$ & $\begin{array}{l}\text { 19. TTIP will increase pressure on employment } \\
\text { issues - lower wages and social standards. } \\
\text { 20. TTIP constitutes a threat to the welfare } \\
\text { state. } \\
\text { 21. CETA infringes EU law. } \\
\text { 22. There is no place for public utility services } \\
\text { in commercial contracts. } \\
\text { 23. Services of general interest will not be } \\
\text { protected. } \\
\text { 24. Regional development is more important } \\
\text { than global public procurement markets. } \\
\text { 25. TTIP will open the way for genetic } \\
\text { engineering. } \\
\text { 26. Commercial contracts destroy family } \\
\text { farms. } \\
\text { 27. TTIP weakens consumer protection in } \\
\text { agriculture. } \\
\text { 28. There are legitimate customs duties and } \\
\text { prohibitions on the import of foodstuffs. } \\
\text { 29. TTIP constitutes a threat to the } \\
\text { precautionary principle applied to chemical } \\
\text { substances. } \\
\text { 30. TTIP - a wrong way for energy policy. } \\
\text { 31. TTIP and CETA threaten the regulation of } \\
\text { financial markets. } \\
\text { 32. TiSA - a threat to public services. } \\
\text { 33. TiSA - unlimited freedom for financial } \\
\text { corporations. } \\
\text { 34. TTIP subordinates the culture of commerce. } \\
\text { 35. Positive thinking instead of negative } \\
\text { actions. } \\
\text { 36. TTIP sacrifices our personal rights. } \\
\text { 37. An alternative trade mandate indicates the } \\
\text { right direction. } \\
\text { 38. Attempts to secure the rights of corporations } \\
\text { often fail. }\end{array}$ \\
\hline
\end{tabular}

*OIRA - Office of Information and Regulatory Affairs - part of the Office of Management and Budget within the Executive Office of the President of the United States.

Source: author's own elaboration based on [Klimenta et al. 2015].

Non-governmental organizations treat preferential trade agreements as a threat to democracy and sovereignty. In this context, mainly the issue of the investor-state dispute settlement system is referred to. According to opponents of the agreement, the ISDS mechanism (investor-state dispute settlement) is an instrument overly strengthening the role of international enterprises. Signing TTIP would give companies the right to lodge complaints against governments concerning decisions that could harm future profits of enterprises, thus undermining democratic decisions 
made in the public interest. Non-governmental organizations, including Friends of the Earth Europe, emphasize that negative decisions of the arbitration court may expose European states not only to huge damages, but they may also have a negative impact on regulatory capacity of states in many socially important areas, including environmental protection. More stringent environmental standards affecting the costs of corporation activities could be appealed as part of the arbitration procedure [Friends of the Earth Europe 2014]. Non-governmental organizations expressed their opposition to the inclusion of the ISDS mechanism into TTIP among others in a letter to Michael Froman, United States Trade Representative (USTR) and Karel De Gucht, Commissioner for Trade, which was signed by nearly two hundred such entities in December 2013 [https://corporateeurope.org...]. Forty-three of them are organizations operating in the United States, 120 in Europe, 4 in Africa, 1 in Asia and 2 in South America. Seven organizations which signed the letter had a global nature or function both in the United States and in the European Union. Among German non-governmental organizations the letter was signed by 29 entities $^{4}$.

Another threat to the natural environment would be to align the standards of protection to the level in force in the United States (the so-called levelling down) [http://stop-ttip-muenchen.de]. In the European Union and the United States, there are differences regarding among others the use of chemicals to protect plants. Many of such agents used in the USA are banned on the European market. In addition, there are differences regarding limits of acceptable food contaminants [Fischer 2015].

The issue of food safety is another problem which opponents of transatlantic trade agreements draw attention to. Sanitary and phytosanitary standards in the European Union, the United States and Canada are often different. There are concerns that the European market will be flooded not only with cheap food with low standards, but also products potentially harmful to the health of consumers, such as e.g. beef from animals whose growth was stimulated by growth hormones previously absent on the European market. It is also argued that TTIP will facilitate access to the European

${ }^{4}$ They were the following organizations: A G Post-Fossil; Arbeitsgemeinschaft bäuerliche Landwirtschaft (ABL); Arbeitskreis Heckenschutz; ATTAC Darmstadt; ATTAC Germany; Attac Gruppe Schwalm-Eder; ATTAC Stuttgart; Attac Wuppertal (Agrargruppe); Berliner Wassertisch (Berlin Watertable); BUND e.V. - Friends of the Earth Germany, Bürgerinitiative Fracking freies Hessen; Bürgerinitiative für ein lebenswertes Korbach; Campact e.V.; Chaos Computer Club e.V.; Deutsche Umweltstiftung; Deutscher Berufs- und Erwerbsimkerbund e.V Deutscher Naturschutzring (DNR); DIVaN e.V.; Forschungs- und Dokumentationszentrum Chile-Lateinamerika e.V.; Gemeingut in BürgerInnenhand (GiB); German Nature and Biodiversity Conservation Union (NABU), BirdLife partner; German NGO Forum on Environment and Development; Germanwatch; NaturFreunde Deutschlands; No Moor Fracking; PEGAH - Verein für regionale und globale Kunst und Kultur / Iranischer Kunst- und Kulturverein; Piratenpartei, Germany PowerShift e.V.; Slow Food Deutschland e.V.; Therapeutikum Wuppertal e. V.; Wasser in Bürgerhand (WIB); World Economy, Ecology \& Development (WEED). 
market for genetically modified products (GMO). Non-governmental organizations are mostly concerned that the EU may resign from the currently applicable precautionary principle and with the potential possibility of harmonization of food standards, adjusting them to the rules in force in the USA or lowering the currently applied regulations to achieve a compromise solution acceptable to the other party [Hajdukiewicz 2015].

The impact of TTIP on the public services sector is also considered. Threats that may be brought by liberalization and deregulation in the case of health care, education, water supply or public transport services are pointed out. According to non-governmental organizations, adopting a model of trade liberalization in services based on the North American Free Trade Area (system of negative lists [Wróbel 2009]) within the agreement, failing to exclude public services from the scope of liberalization, may negatively affect the possibility to regulate such sectors by the state, limiting the impact on choices concerning ownership, management, delivery or control of public services. A lot of attention in NGOs' materials concerning public services is drawn to the need to guarantee the right of access to drinking water [Gendries 2017; Kummerfeld 2015]. This issue constitutes an area of special concern of non-governmental organizations since the inclusion of the sector of services in multilateral negotiations during GATT Uruguay Round, which resulted in the General Agreement on Trade in Services (GATS). NGOs drew attention to threats arising from taking over control of distribution of water by international corporations, including in particular an increase in prices of distribution services, which may very negatively affect the health of people and animals in particular in developing countries due to a difficult access to drinking water [WWF, CIEL 2003].

Threats related to the activity of transnational corporations are also discussed in the context of liberalization of financial services and protection of personal data. In view of the negative experiences associated with the crisis in 2008, NGOs are concerned about the adverse impact of liberalization of the financial services market on the adopted new and more restrictive financial sector regulations. In terms of personal data protection, opponents of TTIP stress that this agreement can be used to re-introduce central elements of ACTA (Anti-Counterfeiting Trade Agreement), creating a threat to the protection of privacy of citizens of European countries, processed by corporations providing personal data communication services in an uncontrolled manner.

An important element of TTIP criticism is a potential impact of the agreement on reducing protection of workers' rights on the European market, bringing them closer to the level of American standards. In this context, the fact that the United States has not ratified many of the key conventions of the International Labour Organization (ILO) is underlined and differences in the approach to safety at the workplace are pointed out.

In the German debate concerning consequences of trade liberalization based on preferential trade agreements, the matter of protecting cultural diversity is 
also discussed. The German Culture Council, an organization gathering cultural organizations and associations in Germany, was one of the non-governmental entities that encouraged citizens to participate in demonstrations against TTIP and CETA. In line with the profile of its activities, this organization emphasized threats to cultural institutions associated with the functioning on the free market. It was highlighted that numerous cultural institutions could not function without public support and potential court cases brought by American institutions of the same type related to unequal treatment on the European market due to the lack of similar support were indicated. Criticism of the Culture Council is largely aimed at the CETA agreement due to the fact that, unlike Canada, the EU did not exclude cultural and audio-visual services from the scope of the agreement [Stasik 2014].

The main objection of non-governmental organizations to trade negotiations is the negotiation process itself, its secret nature and the fact that citizens have no influence on its progress, while corporate lobbyists play an important role in them. To increase transparency of negotiations NGOs published confidential negotiation materials. The negotiating mandate of the European Union was shared on their website before it was made public. In May 2016 Greenpeace displayed the content of thirteen chapters of the TTIP together with the negotiating positions of the parties on the façade of Reichstag in Berlin and published it on their website [Rozwadowska 2016b].

Non-governmental organizations also pay attention to effects of the agreement on the international order and third countries. It is underlined that the creation of such a large trading block as TTIP may be a factor initiating a new confrontation between political and economic blocks [Klimenta et al. 2015]. In analyses dedicated to the genesis of the agreement, there are also statements drawing attention to the fact that TTIP constitutes an attempt to maintain economic domination of the West towards dynamically developing emerging markets. Creation of such a block would certainly cause a response of the southern countries aspiring to play an increasingly important role not only in international economy, but also in political relations, in particular China, Russia, Brazil and India.

Non-governmental organizations also underline the possibility of negative effects of transatlantic trade agreements for the countries of the South. According to them, if the TTIP is signed, the countries of the South will be under great pressure to apply TTIP standards to avoid commercial losses. It was underlined that business lobby openly strives for global convergence towards EU-US standards. This would impose free trade policy on poorer countries which under the pressure of stronger partners would assume regulatory standards negative for them. Additionally, it is possible that the already existing disparities between the countries of the North and the South would be deepened. In her speeches, the head of the Bread for the World organization (Brot für die Welt) Cornelia Füllkrug-Weitzel drew attention to the fact that: "if TTIP and CETA agreements are signed, the "poorest of the poor" will suffer": CETA and TTIP are in conflict with the value-oriented trade policy. 
They will broaden the gap between the leading industrialized nations, the rich North and the poor South. To make sure that trade is a driver of sustainable development, we need fair agreements with higher - and not lower - social and environmental standards" [Rozwadowska 2016a].

Analysing the above-mentioned arguments of non-governmental organizations, it should be stated that the majority of them have a propaganda-like nature aimed at inducing specific social attitudes. In the case of many of them, it is relatively easy to challenge their validity referring to the European Union's current practice, the provisions contained in the applicable trade agreements and their consequences.

Commercial agreements do not limit regulatory rights of the European Union and individual Member States. They do not change principles and procedures of the law-making process. They do not limit the possibility of introducing regulations concerning e.g. health protection, human and animal life through sanitary and phytosanitary standards and technical standards. They also do not limit the possibility of introducing restrictive prudential standards on the financial market. The trade agreements concluded by the European Union contain clauses confirming the regulatory rights. The limitation that occurs in this area is the prohibition of discrimination, which means that new even more restrictive standards may be introduced after the conclusion of trade agreements if they concern both domestic and foreign entities coming from the country with which the EU has signed agreements. The EU has not accepted obligations harmonizing applicable technical, sanitary and veterinary standards in any of the trade agreements concluded so far; no decision was taken to recognize the equivalence of EU regulations with the standards in force in a partner country with which the EU entered into a trade agreement. Therefore, it should not be expected in the case of TTIP. Both parties of negotiations underline that applicable standards will not be lowered. A good point of reference in order to solve concerns about the EU standards that have been in force so far are the provisions of the already negotiated CETA agreement. In art. 21.2 item 4 referring to regulatory cooperation principles we read: "Without prejudice to the ability of each Party to carry out its regulatory, legislative and political activities, the Parties undertake to further develop regulatory cooperation in the light of their common interests in order to: a) prevent and eliminate unnecessary trade and investment barriers; b) create conditions conducive to competitiveness and innovation, including through ensuring regulatory compliance, recognition of equivalence and convergence; and c) support a transparent, efficient and effective regulatory process that supports the implementation of public policy objectives and the fulfilment of tasks by regulators, including through the promotion of information exchange and the dissemination of best practices [Comprehensive Economic...]".

Here, provisions of art. 5.6 concerning the equivalence of sanitary and phytosanitary measures should also be referred to. In the article it has been stated that "the importing Party accepts the sanitary and phytosanitary measure of the exporting Party as equivalent to its measure if the exporting Party objectively 
demonstrates to the importing Party that this measure leads to the sanitary and phytosanitary protection required by the importing Party [Comprehensive Economic...]". In accordance with these provisions, imported goods must correspond to standards applied in the country of the importing party. Therefore, the introduced regulations do not lower the previous level of consumer protection. At the same time, a basis for regulatory cooperation between partners was created. Cooperation in this field is extremely important due to the possibility to use technical, sanitary and phytosanitary barriers as tools of protectionist policy. In the case of significant reduction in customs in trade policy as an effective tool to protect the market since the $70 \mathrm{~s}$ of the $20^{\text {th }}$ century, an increase in the significance of non-tariff barriers in trade policy was observed (the so-called neoprotectionism). Cooperation in terms of regulations concerning the above-mentioned barriers should be perceived positively. Its purpose will be an effective protection of consumers and elimination of situations when technical, sanitary and phytosanitary standards are used as tools of protectionist trade policy.

It should also be underlined that the mechanism to settle investor-state disputes through arbitration and not national courts is not a new solution. These types of mechanisms are used in bilateral investment agreements. An example is the PolishAmerican agreement on the promotion and mutual protection of investments from 1990. Introduction of an appealing mechanism seems to be a good solution in this case like in the case of CETA. CETA establishes a permanent court which settles complaints filed based on art. 8.23 of CETA. Additionally, to control decisions made by the court pursuant to art. 8.28, the Court of Appeal was established which may change or annul a decision of the court.

Significant activity of non-governmental organizations drawing attention to the secretive nature of negotiations contributed to greater transparency of trade negotiations conducted by the European Union. Negotiations of TTIP constitute an example here; in the case of the negotiations the public gained significant access to information on their progress and the European Union's negotiating position. Not only was the negotiating mandate of the European Commission published, but also the position of the EU concerning particular parts of the agreement. Also, consultations with stakeholders of the agreement were carried out, among others the issue of the dispute resolution mechanism bringing about a lot of controversies was broadly consulted ${ }^{5}$. The report on the consultations was also published on the website of the European Commission [European Commission 2015].

However, similar transparency in terms of trade negotiations is absent on the other side of the pond. On the website of the United States Trade Representative (USTR) only basic information about TTIP is available [https://ustr.gov/ttip]. There is no information about the negotiation position of the United States. Such a situation

5 Social consultations on the subject took place from March to July 2014; within such consultation the European Commission received 149,399 responses from the entire EU in total [Siles-Brügge, De Ville 2016]. 
may result from smaller than in Europe activities of non-governmental organizations in the United States and smaller interest of the US society in the negotiation process. Much larger interest was observed in the case of negotiations concerning the Transpacific Partnership (TPP).

Non-governmental organizations - as mentioned in the first part of the article - not only undertake actions against trade negotiations aimed at ceasing the trade liberalization process, drawing attention to threats related to it. There are also non-governmental organizations which support the process. In terms of TTOP negotiations, an example illustrating such activities is a joint open letter to the European Parliament, the European Council, the European Commission and the national parliaments of the EU Member States signed by fourteen think tanks from Central-Eastern Europe constituting 4liberty.eu' ${ }^{6}$. These organizations urged "representatives of the European Commission, European Parliament and national parliaments to make a decision based on material economic evidence supported with studies and to accept TTIP and all its elements, including the ISDS mechanism" [An open letter...]. Authors of the letter drew attention to economic benefits of trade liberalization, underlining that in the case of developed countries liberalization brings clear, tangible economic benefits for all involved entities, although the size and distribution of these benefits between trading partners may be the subject of discussion. Attention was also drawn to that fact that "greater freedom of trade (...) results in the growth of prosperity, and not its decline" [An open letter...]. Positive experience of trade liberalization on the internal European Union market for which liberalization did not mean a limitation of consumer protection was referred to as an illustration of benefits of free trade [An open letter...]. Also in Germany we will find numerous non-governmental organizations drawing attention to benefits resulting from trade liberalization, including TTIP and CETA. Such organizations are not only think tanks, but also industry organizations, seeking possibilities for further development of German economy in opening new markets [https://www.boell.de].

Different approaches to preferential trade agreements in Germany can be observed not only in the case of employers' associations, trade unions, think tanks, environmental organizations and other non-governmental organizations, but also among the main political parties. From the very beginning of negotiations, CDU pointed out the benefits of TTIP. For Christian Democrats, the agreement is a "bridge to the future", favouring the creation of new jobs in the export sector. A sister party of $\mathrm{CDU}$ also presents a similar positive approach to transatlantic negotiations.

\footnotetext{
6 Academy of Liberalism (Estonia), Centre for Liberal Studies (Czech), CETA - Centre for Economic and Market Analyses (Czech), Civil Development Forum - Forum Obywatelskiego Rozwoju FOR (Poland); F.A. Hayek Foundation (Slovakia); Industrial Foundation Liberté! (Poland); Hungarian Free Market Foundation (Hungary); Institute for Market Economics (Bulgaria), Institute of Economic and Social Studies (Slovakia), Lithuanian Free Market Institute (Lithuania), Project: Poland (Poland), Republikon Institute (Hungary), Svetilnik - Association for Promotion of Freedom (Slovenia), Visio Institute (Slovenia).
} 
Supporting TTIP and CETA, CSU simultaneously underlines that negotiations should be carried out in a more transparent manner. Attention was also drawn to the need to maintain a high level of European quality and safety standards. Similar postulates were presented in the statements of SPD representatives. Transatlantic trade agreements were very positively perceived by FDP due to opportunities for German economy. An opposing position was observed from the very beginning of TTIP negotiations in the case of the Green, (Bündnis 90/Die Grünen), Die Linke, the Pirate Party and the German Communist Party (DKP). On the other hand, the Alternative for Germany (AfD) undermined the competence to conduct negotiations, drawing attention to the fact that a beneficial agreement could be negotiated only with the participation of representatives of the Member States [Baron 2016]. It is hard to determine the impact of non-governmental organization on the above-mentioned positions of German political parties. Surely, presenting their attitude to preferential trade liberalization, such parties consider the possibility to get support in the election process. Analysing the impact of NGOs on activities of political parties, it can be certainly argued that they presented their opinions on actions of such entities, criticizing or supporting their activity. Examples of initiatives supported by nongovernmental organizations as well as by some German political parties opposing TTIP and CETA involve encouragement to participate in the above-mentioned protests urging to cease negotiations with the US and Canada.

\section{Conclusions}

Summarizing the above considerations, it should be stated that in recent years an increase in significance of non-governmental organizations in the decision-making process concerning trade policy is observed. Obviously, non-governmental organizations are not entities making such decisions, but their significant activity and impact on the public cause that authorities have to take postulates presented by such entities into consideration. Specificity of the European Union causes that striving to achieve goals in the area of trade policy NGOs undertake activities aimed at shaping the positions of individual countries in which they conduct their activities, but also institutions of the European Union, in particular the European Commission and the European Parliament. Undertaken activities vary in effectiveness. A spectacular success of non-governmental organizations was the failure of the ACTA agreement. The current lack of progress in TTIP negotiations should not be associated with the activity of non-governmental organizations - in this case political factors related to the change in the policy of the United States occurring as a result of Donald Trump taking up his position play a deciding role. However, it does not mean that NGOs have not affected the course of the public debate concerning transatlantic trade negotiations, and therefore also the positions of governments and actions of EU institutions. 
An example of an effective influence of non-state entities is a broad discussion concerning the ISDS mechanism in TTIP and evolution maybe not of the position, but of rhetoric of particular Member States in this field. EU Member States which previously supported inclusion of ISDS into the EU negotiating mandate, seemed to change their rhetoric concerning this matter. For instance, in March 2014 Germany, which due to their position in global trade, have a proliberal approach in trade policy, for the first time assumed a critical position on the inclusion of ISDS into TTIP; a similar position was then presented by other Member States and several national parliaments. During the elections to the European Parliament, held in May 2014, several European political parties also expressed their critical attitude towards TTIP, especially in reference to ISDS. At that time, both the European Green Party and the United European Left criticized TTIP negotiations and opposed arbitration courts for investors. Referring to another threat pointed out by non-governmental organizations, i.e. the possibility of lowering standards concerning food, the symbol of which were "chlorinated chickens", parties supporting TTIP negotiations assumed a soothing attitude. For instance, Jean-Claude Juncker, a candidate for the President of the Commission of the European People's Party positively oriented towards TTIP, during the election campaign in the European elections, stressed that lowering standards is not negotiable [Siles-Brügge, De Ville 2016]. Also in Germany, to calm the public, Chancellor Angela Merkel repeatedly stated that the previous consumer protection will be maintained [Brauns 2016].

Campaigns of non-governmental organizations against CETA and TTIP negotiations also had a direct impact on works of the European Commission which carried out information campaigns concerning the course and purpose of negotiations as well as campaigns indicating that the threats pointed out by NGOs did not exist. Cecilia Malmström, Commissioner for Trade, extended actions towards transparency of negotiations initiated by her predecessor Karel De Gucht. Consequently, among others the Commission's negotiating mandate in TTIP negotiations was published and confidentiality rules regarding access of the European Parliament Members to negotiating documents were changed, and in particular a large number of negotiation texts submitted by the EU during the negotiations were published. Such actions were of a worldwide unique nature. We had not experienced such openness in previous negotiation processes conducted by the EU. In January 2015 the European Commission also published a report concerning consultations on ISDS, in which common opposition to this principle was included and numerous improvements in the arbitration system for investors were suggested [Brauns 2016].

Actions undertaken by non-governmental organizations against preferential trade agreements constitute the continuation of activities of anti/alter-globalists from the $90 \mathrm{~s}$ of the $20^{\text {th }}$ century. Currently, through the popularization of the Internet and access to social media, they obtained new tools which are effectively used to inform about threats resulting from trade liberalization, at the same time gaining social support for the initiatives they implement. Initiatives undertaken 
by non-governmental organizations ensure greater dynamics of the public debate in EU Member States concerning joint trade policy. Such actions are important as they bring problems settled at the supranational level closer to societies and force enthusiasts of trade liberalization to defend their position. At the same time, societies have more information about arguments presented by opponents and enthusiasts of free trade?

\section{References}

10 Gründe, warum Sie wegen TTIP besorgt sein sollten, http://stop-ttip-muenchen.de/10-gruendewarum-sie-wegen-ttip-besorgt-sein-sollten (access; 10.12.2017).

An open letter to representatives of the European Parliament, European Council, European Commission and national parliaments of EU member states, http://4liberty.eu/an-open-letter-on-ttip-in-polish (access: 20.12.2017).

Baron Ch., 2016, Wie stehen die Parteien zu TTIP? https://www.neues-deutschland.de/artikel/1009559. wie-stehen-die-parteien-zu-ttip.html, (access: 20.12.2017).

Brauns B., 2016, Das unmögliche Versprechen, http://www.zeit.de/wirtschaft/2016-05/ttip-eu-usagreenpeace-leak-verbraucherschutz-freihandelsabkommen (access; 20.12.2017).

Comprehensive Economic and Trade Agreement, http://ec.europa.eu/trade/policy/in-focus/ceta/cetachapter-by-chapter/index_pl.htm (access: 20.12.2017).

European Commission, 2015, Commission Staff Working Document, Report Online public consultation on investment protection and investor-to-state dispute settlement (ISDS) in the Transatlantic Trade and Investment Partnership Agreement (TTIP), Brussels, 13.01.2015 SWD(2015) 3 final, http:// trade.ec.europa.eu/doclib/docs/2015/january/tradoc_153044.pdf (access: 20.12.2017).

Fischer H., 2015, TTIP: Wolny handel na koszt środowiska? Wielka demonstracja w Berlinie, http:// www.dw.com/pl/ttip-wolny-handel-na-koszt-\%C5\%9Brodowiska-wielka-demonstracja-wberlinie/a-18773625 (access: 15.12.2017).

Friends of the Earth Europe, 2014, The Hidden Cost of EU Trade Deals: investor-State Dispute Settlement Cases Taken Against EU Member States, https://www.foeeurope.org/sites/default/files/ publications/hidden_cost_of_eu_trade_deals_1.pdf (access; 10.12.2017).

Gendries S., Zwei Bürgerinitiativen für das Recht auf Wasser: Right2Water und Stop TTIP, http://www. lebensraumwasser.com/?p=3748 (access: 15.12.2017).

Hajdukiewicz A., 2014, Kwestie dotyczace rolnictwa w negocjacjach Transatlantyckiego Partnerstwa w dziedzinie Handlu i Inwestycji, International Business and Global Economy 2014, no. 33.

Hoekman B., Kostecki M.M., 2002, Ekonomia światowego systemu handlu. WTO: Zasady i mechanizmy negocjacji, Wydawnictwo Akademii Ekonomicznej im. Oskara Langego we Wrocławiu, Wrocław. https://www.boell.de (access: 10.12.2017).

https://corporateeurope.org/sites/default/files/attachments/ttip_investment_letter_final.pdf (access: 10.12.2017).

https://stop-ttip.org/about-stop-ttip (access: 10.12.2017).

http://stop-ttip-muenchen.de, (access: 10.12.2017).

https://ustr.gov/ttip (access: 20.12.2017).

https://www.neues-deutschland.de/artikel/1009559.wie-stehen-die-parteien-zu-ttip.html ～(access: 20.12.2017).

7 The paper first published in Polish in Studia Politica Germanica 1-2/2017. 
Hueyer S., 2004, Challenging relations: a labour-ngos coalition to oppose the Canada-US and North American free Trade Agreements 1985-93, Development in Practice", vol. 14 (1-2).

Klimenta H., Strasser M., Fuchs P., Bank M., Bär K., Efler M., Fritz T., Fuchs P., Goebel H., Hartmann A., Henn M., Hilbig S., Hintze R.H., Klimenta H., Knirsch J., Maier J., J. Passadakis A.J., Reetz C., Reuter K., Sawatzki A., Schaffert A., Schulze K.O., Stolper E.Ch., Strasser M., Sundermann J., Tangens R., Then Ch., Vengels J., Wötzel U., Zimmermann O., 2015, 38 Argumente gegen TTIP, CETA, TISA \& Co., Für einen zukunftsfähigen Welthandel, AttacBasisTexte 48, VSA: Verlag, Hamburg, pp. 14-15.

Kummerfeld C., 2015, TTIP: So könnten US-Konzerne Wasser in Europa zu Gold machen, https:// finanzmarktwelt.de/ttip-so-koennten-us-konzerne-wasser-in-europa-zu-gold-machen-10986 (access: 15.12.2017).

Metzner I.D., 2014, Zebrali milion podpisów od przeciwników TTIP. Na sukces nie maja co liczyć, http://www.dw.com/pl/zebrali-milion-podpis $\% \mathrm{C} 3 \% \mathrm{~B} 3 \mathrm{w}$-od-przeciwnik\%C3\%B3w-ttip-nasukces-nie-maj\%C4\%85-co-liczy\%C4\%87/a-18112816 (access: 15.12 .2017 ).

Murphy H., 2010, The Making of International Trade Policy NGOs, Agenda-Setting and the WTO, Edward Elgar Publishing, Cheltenham.

Rozwadowska A., 2016a, TTIP i CETA: Niemcy będq protestować, Austriacy zbieraja podpisy, http://wyborcza.pl/1,155290,20588786,ttip-i-ceta-niemcy-beda-protestowac-austriacy-zbierajapodpisy.html?disableRedirects=true (access: 15.12.2017).

Rozwadowska A., 2016b, TTIP Leaks. Greenpeace ujawnia część treści TTIP. Mocne ograniczenia praw konsumenta?, http://wyborcza.pl/1,155290,20008826,ttip-leaks-greenpeace-ujawnia-czesc-tresci -ttip-mocne-ograniczenia.html (access: 15.12.2017).

Siles-Brügge G., De Ville F., 2016, NGOs und die TTIP-Verhandlungen, https://netzpolitik.org/2016/ ngos-und-die-ttip-verhandlungen (access: 20.12.2017).

Stasik E., 2016, Niemcy: Masowe protesty przeciwko TTIP i CETA, http://www.dw.com/pl/niemcymasowe-protesty-przeciwko-ttip-i-ceta/a-19210222 (access: 15.12.2017).

Stasik E., 2014, Niemcy: Rada Kultury zapowiada rebelie przeciw transatlantyckim umowom, http:// www.dw.com/pl/niemcy-rada-kultury-zapowiada-rebeli\%C4\%99-przeciw-transatlantyckimumowom/a-18163811 (access: 15.12.2017).

Stillerman J., 2003, Transnational Networks and the Emergence of Labour Internationalism in the NAFTA Countries', Social Science History, vol. 27(4), pp. 577-601.

Strange M., 2014, Writing Global Trade Governance. Discourse and the WTO, Routledge, London, New York.

T-754/14 - Michael Efler vs. European Commission, http://curia.europa.eu/juris/documents. jsf?num=T-754/14 (access: 15.12.2017).

TTIP bedroht nachhaltige Wassernutzung, http://forumue.de/wp-content/uploads/2015/06/AG_ Handel_PM_zum_Weltwassertag.pdf (15.12.2017).

Wer sind die Befürworter/innen, wer die Gegner/innen des Transatlantischen Freihandelsabkommens - und wie argumentieren sie?, 2014, https://www.boell.de/de/2014/05/12/6-wer-sind-diebefuerworterinnen-wer-die-gegnerinnen-des-transatlantischen (access: 20.12.2017).

Willestts P., 2008, Aktorzy transnarodowi i organizacje międzynarodowe w polityce globalnej, [in:] J. Baylis, S. Smith (eds.), Globalizacja polityki światowej. Wprowadzenie do stosunków międzynarodowych, Wydawnictwo Uniwersytetu Jagiellońskiego, Kraków, pp. 537-538.

Wróbel A., 2009, Międzynarodowa wymiana ustug, Wydawnictwo Naukowe Scholar, Warszawa.

WWF, CIEL, 2003, GATS, Water and the Environment: Implications of the General Agreement on Trade in Services for Water Resources, CIEL and WWF International Discussion Paper, Geneva, http://www.ciel.org/Publications/GATS_WaterEnv_Nov03.pdf (access: 15.12.2017). 